\title{
STUDI BANDING JENIS-JENIS FONDASI RAFT PILE DENGAN ASUMSI FRICTION PILE UNTUK GEDUNG KAMPUS II UNIVERSITAS TARUMANAGARA
}

\author{
Hanif $^{1}$ dan Gregorius Sandjaja Sentosa ${ }^{2}$ \\ ${ }^{1}$ Program Studi Sarjana Teknik Sipil, Universitas Tarumanagara, Jl. Letjen S. Parman No.1 Jakarta \\ Email: hanifaffansalim@gmail.com \\ ${ }^{2}$ Program Studi Sarjana Teknik Sipil, Universitas Tarumanagara, Jl. Letjen S. Parman No.1 Jakarta \\ Email: gregoriuss@ft.untar.ac.id
}

\begin{abstract}
ABSTRAK
Fondasi bangunan tinggi lebih dari 20 lantai pada tanah dengan kondisi lunak sampai sedang (N-SPT rata-rata < 30) biasanya bisa digunakan salah satunya dengan fondasi tiang rakit. Pemilihan jenis fondasi dapat berupa tiang pancang atau tiang bor. Dalam skripsi ini, dilakukan studi fondasi bangunan 24 lantai pada lapisan tanah dominan lanau dengan N-SPT rata-rata 20-30, dan ada nilai NSPT 40-60 tetapi berupa lapisan tipis. Studi dilakukan dengan mengasumsikan fondasi dengan tiang pancang dengan sisi 0,6 m dan tiang bor berdiameter $1 \mathrm{~m}$ dengan panjang tiang 34,5 $\mathrm{m}$ dan $47 \mathrm{~m}$. Studi dilakukan dengan menghitung daya dukung dan penurunan menggunakan pendekatan rumusrumus berdasarkan korelasi dari data N-SPT dan N-SPT serta simulasi PLAXIS untuk mengetahui besarnya tegangan di sekitar fondasi dan penurunan yang terjadi. Dari hasil studi banding tersebut diperoleh penurunan yang terjadi pada panjang tiang 34,5 m sebesar 15-21 cm sedangkan pada panjang tiang $47 \mathrm{~m}$ diperoleh penurunan sebesar 10-14 cm. Daya dukung yang diperoleh pada tiang pancang tunggal berkisar 145-391 Ton dan daya dukung tiang bor tunggal berkisar 254-612 Ton pada panjang tiang 34,5 m. Jumlah tiang pancang kelompok yang diperoleh berkisar 130-391 tiang dan jumlah tiang bor kelompok berkisar 88-252 tiang dengan panjang tiang 34,5 m.
\end{abstract}

Kata kunci: Tiang Pancang, Tiang Bor, Daya Dukung, Penurunan, PLAXIS.

\section{PENDAHULUAN}

\section{Latar Belakang}

Fondasi merupakan bagian dari struktur bangunan yang terletak paling bawah bangunan. Fondasi berperan penting dalam struktur bangunan karena kegagalan dari struktur tersebut dapat mengakibatkan kegagalan pada seluruh bangunan. Fondasi berfungsi menyalurkan gaya atau beban yang bekerja pada struktur atas ke tanah dasar tanpa mengakibatkan penurunan tanah yang berlebihan.

Sejalan dengan akan dibangunnya pada lahan pengembangan di kawasan kampus II Universitas Tarumanagara, yaitu Gedung Rumah Sakit Tarumanagara. Gedung Rumah Sakit Tarumanagara yang akan dibangun berlokasi pada gedung D eksisting yang berfungsi sebagai gedung parkir dan direncanakan memiliki 24 lantai yang terdiri dari fungsi Rumah Sakit dan fasilitas pendidikan untuk ilmu kesehatan.

Setelah ditentukan jenis bangunan yang akan dibangun maka terdapat beberapa alternatif jenis fondasi yang akan digunakan, diantaranya fondasi tiang pancang dan tiang bor. Pemilihan jenis fondasi serta perencanaan fondasi harus dilakukan secara benar. Setiap jenis fondasi tersebut memiliki keuntungan dan kerugian, dimana terdapat beberapa faktor yang harus dipertimbangkan untuk pemilihan jenis fondasi yang tepat dengan daya dukung yang memenuhi syarat kestabilan.

Perhitungan fondasi dalam dapat dilakukan dengan 2 metode, yaitu metode konvensional dan metode elemen hingga yang dapat memodelkan kondisi tanah yang lebih rumit. Program metode elemen hingga yang digunakan yaitu PLAXIS, merupakan aplikasi geoteknik di mana keadaan yang terjadi di lapangan dapat disimulasikan. Diharapkan dalam menggunakan program PLAXIS ini dapat memberikan hasil perhitungan yang mendekati kondisi yang sesuai dengan keadaan di lapangan. 


\section{Batasan Masalah}

Dalam analisis, dibatasi untuk perhitungan lapisan permukaan tiang pancang yang halus dan tiang bor yang kasar. Ukuran penampang fondasi tiang pancang sebesar 0,6 m sedangkan tiang bor $1 \mathrm{~m}$. Perhitungan penurunan fondasi dilakukan berdasarkan penurunan seketika atau jangka pendek. Perhitungan fondasi dalam dilakukan pada daerah tower. Perhitungan dan simulasi digunakan dengan mengambil 1 potongan denah yang terpendek.

\section{Rumusan Masalah}

Rumusan masalah yang akan dibahas adalah perhitungan daya dukung fondasi dalam, perhitungan jumlah tiang yang dibutuhkan untuk fondasi rakit, dan perhitungan penurunan fondasi dalam.

\section{Tujuan Penelitian}

Tujuan penelitian ini adalah menganalisis hasil perhitungan daya dukung fondasi dalam, jumlah tiang yang dibutuhkan untuk fondasi rakit, dan penurunan fondasi dalam berdasarkan jumlah tiang tertentu.

\section{DASAR TEORI}

Fondasi tiang adalah suatu konstruksi fondasi yang mampu menahan gaya orthogonal ke sumbu tiang dengan jalan menyerap lenturan. Fondasi tiang dibuat menjadi satu kesatuan yang monolit dengan menyatukan pangkal tiang pancang yang terdapat di bawah konstruksi, dengan tumpuan fondasi.

Berdasarkan penyaluran beban tanah, fondasi tiang dibedakan menjadi 3, yaitu :

1. Fondasi tiang dengan tahanan ujung (end bearing pile). Tiang semacam ini dimasukkan sampai lapisan tanah keras sehingga daya dukung tanah untuk fondasi ini lebih ditekankan pada tahanan ujungnya.

2. Fondasi tiang dengan tahanan geser (friction pile), merupakan tiang yang tertahan oleh pelekatan antara tiang dengan tanah. Biasanya di ketemukan pada keadaan tanah dimana lapisan tanah keras sangat dalam sehingga pembuatan tiang sampai lapisan tersebut sukar dilaksanakan.

3. Kombinasi antara end bearing capacity dan friction pile.

Parameter tanah yang digunakan dalam analisis didapat menggunakan tabel dan grafik korelasi pendekatan berdasarkan jenis tanah dan nilai N-SPT yang diperoleh dari hasil penyelidikan tanah pada proyek gedung kampus II UNTAR. Parameter-parameter yang dibutuhkan dalam analisis ini adalah berat jenis tanah $\left(\gamma_{\text {unsat }}\right.$ dan $\left.\gamma_{\text {sat }}\right)$, sudut geser dalam $(\Phi)$, koefisien permeabilitas $(\mathrm{k})$, modulus elastisitas tanah (E), angka poisson (v), dan kohesi (c).

Daya dukung fondasi tiang mengikuti rumus umum yang diperoleh dari penjumlahan tahanan ujung dan tahanan selimut tiang, yang dapat dinyatakan dalam bentuk :

$$
\mathrm{Q}_{\mathrm{u}}=\mathrm{Q}_{\mathrm{p}}+\mathrm{Q}_{\mathrm{s}}
$$

Keterangan :

$\mathrm{Q}_{\mathrm{u}}=$ daya dukung ultimit tiang (Ton)

$\mathrm{Q}_{\mathrm{p}}=$ daya dukung ultimit ujung tiang (Ton)

$\mathrm{Q}_{\mathrm{s}}=$ daya dukung ultimit selimut tiang (Ton)

Meskipun pada tiang yang berdiameter besar untuk beban ringan biasanya digunakan fondasi tiang tunggal untuk memikul beban kolom, namun pada umumnya beban kolom dapat dipikul oleh kelompok tiang. Kelompok tiang merupakan sekumpulan tiang yang dipasang secara relatif berdekatan dan dibagian atasnya diikat menjadi satu bagian dengan menggunakan pile cap.

Dalam sistem kelompok tiang, apabila jarak antar tiang cukup dekat maka akan menimbulkan zona tegangan pada ujung maupun keliling tiang yang mengakibatkan terjadinya overlapping pada daerah yang mengalami tegangan akibat beban yang bekerja, seperti terlihat pada Gambar 1. dan Gambar 2. yang menunjukan daerah pengaruh tegangan pada kelompok tiang. Apabila tanah pada daerah overlapping tidak mampu menahan tegangan tersebut maka tanah tersebut runtuh. kebanyakan peraturan bangunan mensyaratkan jarak minimum antara tiang sebesar 2 kali diameter sedangkan jarak optimal antara tiang umumnya adalah antara 2,5-3 kali diameter (Rahardjo, 2017). 


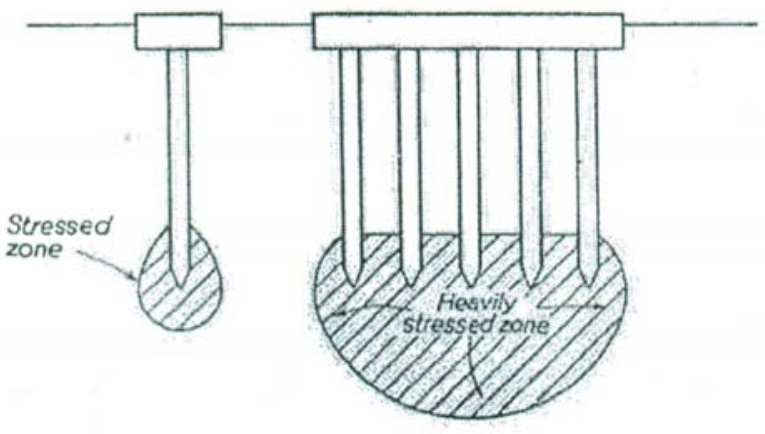

Gambar 1. Tegangan di bawah ujung tiang tunggal dan kelompok (Tomlinson, 1994)

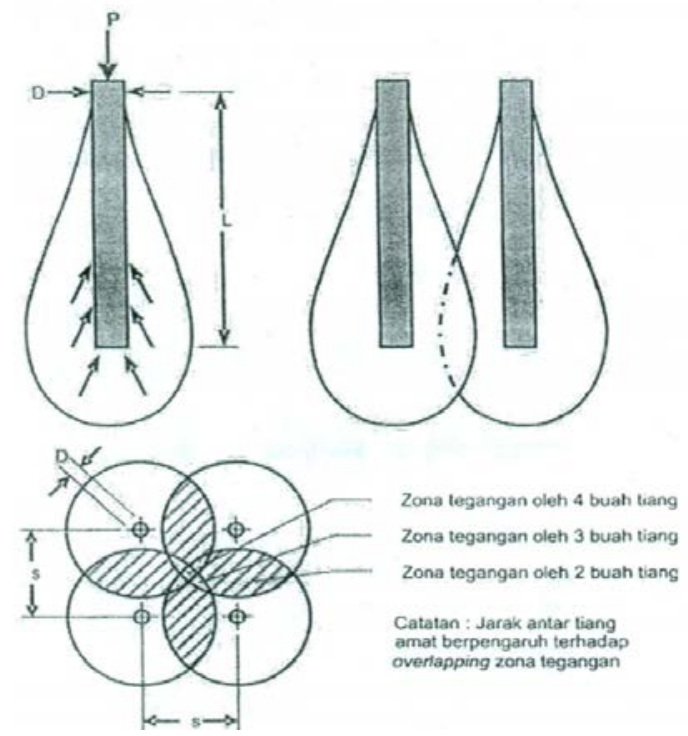

Gambar 2. Ilustrasi overlapping zona tegangan di sekitar kelompok tiang (Bowles, 1997)

Ada beberapa formula efesiensi kelompok tiang yang dapat digunakan yaitu (Rahardjo, 2017) :

1. Formula Sederhana

$$
\mathrm{E}_{\mathrm{g}}=\frac{2 \cdot(\mathrm{m}+\mathrm{n}-2) \cdot s+4 \cdot \mathrm{D}}{\mathrm{p} \cdot \mathrm{m} \cdot \mathrm{n}}
$$

2. Formula Converse-Labarre

$$
\mathrm{E}_{\mathrm{g}}=1-\tan ^{-1}\left(\frac{\mathrm{D}}{\mathrm{g}}\right) \cdot\left[\frac{[\mathrm{n}-1 \mathrm{w} \cdot \mathrm{m}+[\mathrm{m}-1) \mathrm{n}}{90 \cdot \mathrm{m} \cdot \mathrm{n}}\right]
$$

3. Formula Los Angeles

$$
E_{g}=\left[1-\frac{D}{\pi \cdot s \cdot m \cdot n}\right] \cdot[m \cdot(n-1)+n \cdot(m-1)+(m-1) \cdot(n-1) \cdot \sqrt{2}]
$$

4. Formula Seiler-Keeney

$$
E_{g}=\left[1-\frac{36 \cdot s \cdot(m+n-2)}{\left(75 \cdot s^{2}-7\right) \cdot(m+n-1)}\right]+\frac{0, a}{m+n}
$$

Analisa fondasi tiang tunggal dilakukan dengan metode Poulus dan Davis (1980). Perhitungan dilakukan berdasarkan tiang gesekan :

Keterangan :

$$
\rho=\frac{\mathrm{P} \cdot \mathrm{I}}{\mathrm{E}_{\mathrm{s} \cdot \mathrm{d}}}
$$

$\rho \quad=$ penurunan kepala tiang $(\mathrm{m})$

$\mathrm{P}=$ beban aksial yang bekerja $(\mathrm{kN})$

I $\quad=\mathrm{I}_{\mathrm{o}} \cdot \mathrm{R}_{\mathrm{k}} \cdot \mathrm{R}_{\mathrm{h}} \cdot \mathrm{R}_{\mathrm{v}}$

$\mathrm{I}_{\mathrm{o}} \quad=$ faktor pengaruh penurunan tiang untuk $\mathrm{v}_{\mathrm{s}}=0,5$ 
$\mathrm{R}_{\mathrm{k}} \quad=$ faktor koreksi untuk kompresibilitas tiang

$\mathrm{R}_{\mathrm{h}} \quad=$ faktor koreksi untuk kedalaman lapisan tanah hingga tanah keras

$\mathrm{R}_{\mathrm{v}} \quad=$ faktor koreksi untuk angka poisson tanah

Penurunan seketika (Immediately Settelement) merupakan penurunan yang langsung terjadi begitu tanah di bebani, biasanya terjadi berkisar antara 0-7 hari. Penurunan seketika ini terjadi pada tanah lanau, pasir, dan tanah liat yang mempunyai derajat kejenuhan ( $\mathrm{Sr}<90 \%)$.

Perkiraan penurunan tiang kelompok pada tanah kohesif dapat diperkirakan dengan menggunakan tahap berikut dan dapat dilihat pada Gambar 3. (Rahardjo, 2017) :

- Tentukan tegangan yang bekerja :

$$
\mathrm{q}=\frac{\mathrm{Q}}{\mathrm{B}_{\mathrm{g}} \cdot \mathrm{L}_{\mathrm{g}}}
$$

tegangan yang bekerja harus lebih kecil dari tegangan izin tanah.

- Beban kerja di atas kelompok tiang dialihkan pada kedalaman 2/3 dari panjang tiang dibawah pile cap. Penurunan tanah di atas kedalaman tersebut amat kecil dan dapat diabaikan

- Beban kerja yang telah dipindahkan tersebut kemudian disebarkan ke bawah fondasi tiang dengan mengambil asumsi pola penyebaran vertikal : horisontal $=2: 1$

- Hitung penurunan seketika dari tiap lapis, penjumlahan penurunan dari seluruh lapis merupakan penurunan dari kelompok tiang.

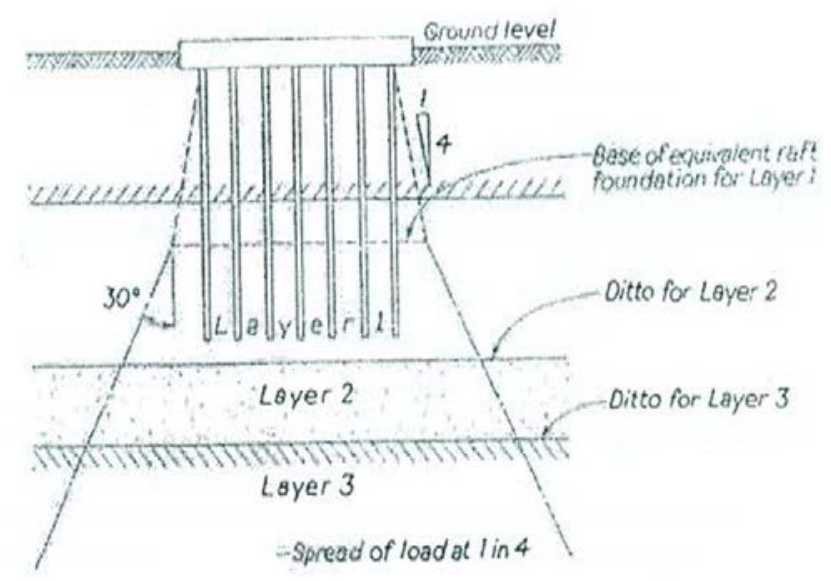

Gambar 3. Distribusi Tegangan untuk Penurunan Tiang Kelompok (Tomlinson,1994)

Untuk menghitung penurunan seketika (Immediately Settlement), dapat dilakukan dengan menggunakan metode Janbu, Bjerrum, dan Kjaernsli sebagai berikut:

$$
\mathrm{Si}=\frac{\mu_{1} \cdot \mu_{0} \cdot \mathrm{q}_{\mathrm{m}} \cdot \mathrm{B}}{\mathrm{E}_{\mathrm{s}}}
$$

Keterangan :

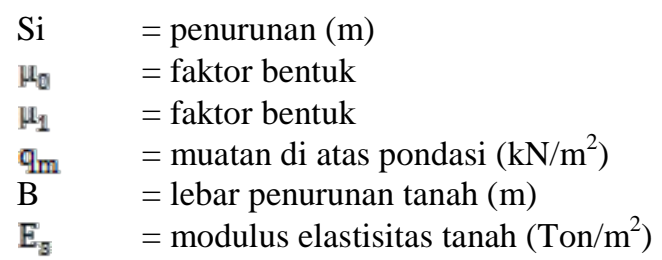

Program finite element yang digunakan dalam analisis adalah program PLAXIS 2D versi 8.2. Kondisi tanah dan pembebanan dimodelkan dalam bentuk elemen. PLAXIS memodelkan elemen tanah dalam bentuk segitiga yang tersambung melalui titik-titik nodal (nodes) serta memiliki kondisi batas (boundaty condition). Bentuk elemen tersebut dapat dilihat pada Gambar 4. Titik tegangan pada elemen 6 nodal dapat dilihat pada Gambar 5. 


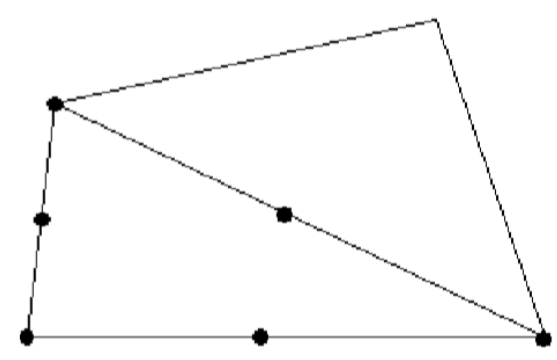

Gambar 4. Elemen 6 nodal (sumber: PLAXIS version 8 Manuals)

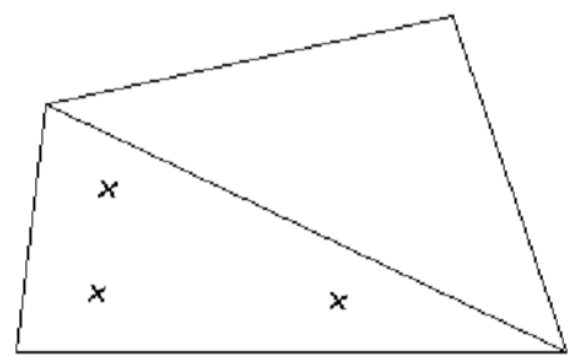

Gambar 5. Titik-titik tegangan elemen 6 nodal (sumber: PLAXIS version 8 Manuals)

\section{METODOLOGI PENELITIAN}

Pada penelitian ini, dilakukan langkah-langkah sebagai berikut seperti Gambar 6 .

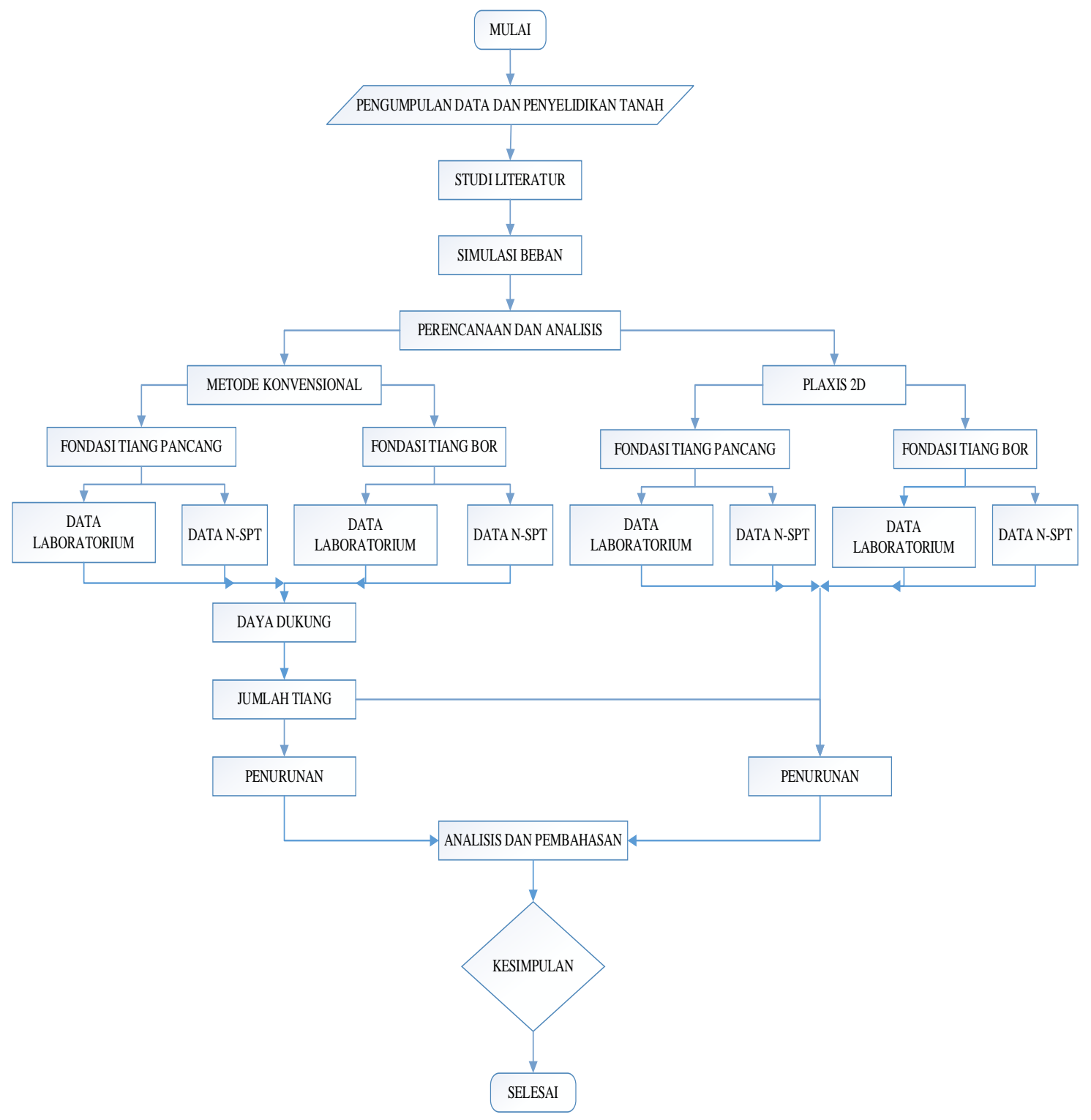

Gambar 6. Diagram alir penelitian 
Metodologi penelitian yang dilakukan pada skripsi ini adalah :

1. Data Perencanaan

Data-data awal yang dimiliki untuk penelitian.

2. Studi Literatur

Pengumpulan teori untuk menganalisis mengenai fondasi dalam dan panduan program PLAXIS berupa buku tutorial.

3. Simulasi Beban Pada Fondasi Dalam

Mensimulasikan beban yang ditahan fondasi dalam.

4. Perencanaan dan Analisis

Mengkorelasi data-data tanah yang ada dan melakukan analisis sesuai dengan kebutuhan penelitian.

5. Hasil Penelitian

hasil perhitungan konvensional dan ouput program PLAXIS.

6. Analisis Hasil

Membandingkan hasil simulasi perhitungan konvensional dengan program PLAXIS.

\section{HASIL DAN ANALISIS}

Dalam analisis ini, terdapat 2 lokasi yaitu daerah tower dan podium yang dapat dilihat pada Gambar 7. Beban gedung atau tower ditahan oleh fondasi di daerah tower saja sedangkan beban pada daerah podium di asumsikan hanya berat sendiri fondasi rakit dengan asumsi jarak antar tiang pada daerah podium lebih renggang dibandingkan jarak antar tiang pada daerah tower untuk dimasukkan kedalam PLAXIS. Berikut nilai beban Gedung Kampus II UNTAR dengan jumlah 24 lantai berdasarkan perhitungan menggunakan program ETABS :

- Berat Gedung = $\quad=402537,72 \mathrm{kN}$

- $\quad$ Beban merata pada daerah tower $=\frac{4025 a 77^{727}}{34,09 \times 4477}=263,7 \approx 265 \mathrm{kN} / \mathrm{m}^{2}$

- Beban merata pada daerah podium $=24 \mathrm{kN} / \mathrm{m} 3 \times 3 \mathrm{~m}=72 \mathrm{kN} / \mathrm{m}^{2}$

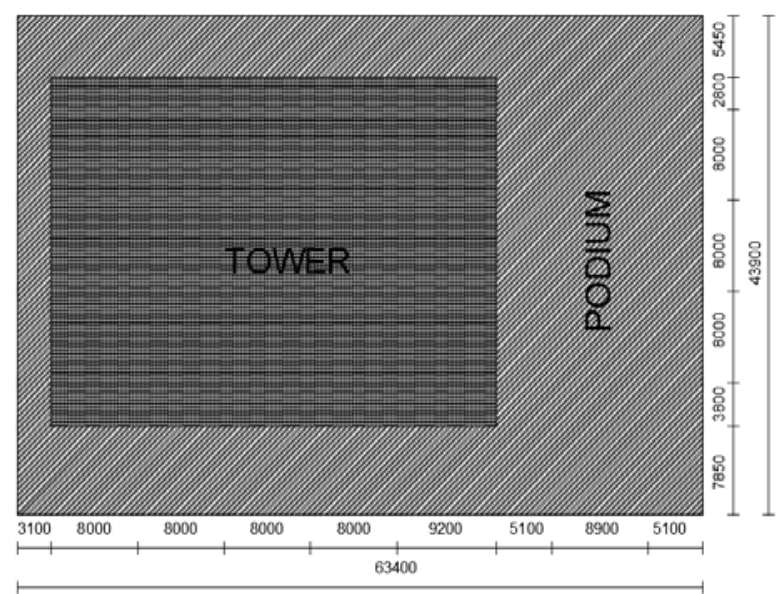

Gambar 7. Denah gedung kampus II UNTAR

Dari hasil perencanaan fondasi perhitungan konvensional didapat nilai daya dukung tiang tunggal pancang dan bor berdasarkan korelasi data N-SPT dan data N-SPT yang dapat dilihat pada Gambar 8. 


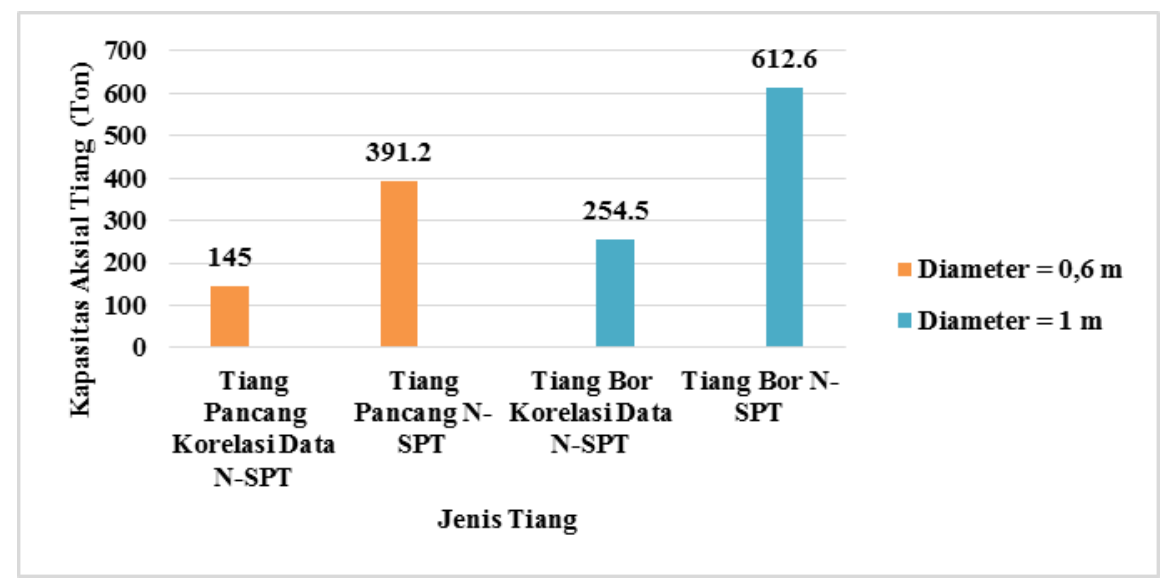

Gambar 8. Kapasitas aksial tiang

Setelah hasil daya dukung tiang tunggal didapat maka dapat ditentukan nilai efesiensi untuk menentukan jumlah tiang, efesiensi yang diambil adalah formula Converse-Labarre yang dapat dilihat pada Gambar 9.

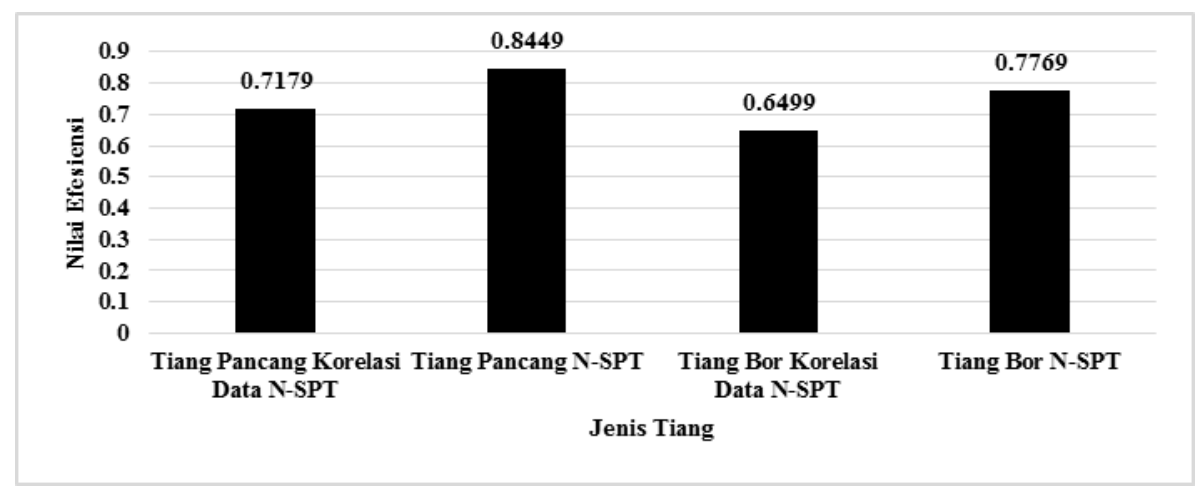

Gambar 9. Nilai efesiensi

Setelah didapat nilai efesiensi maka dapat ditentukan jumlah tiang yang dibutuhkan untuk fondasi raft pile yang dapat dilihat pada Gambar 10.

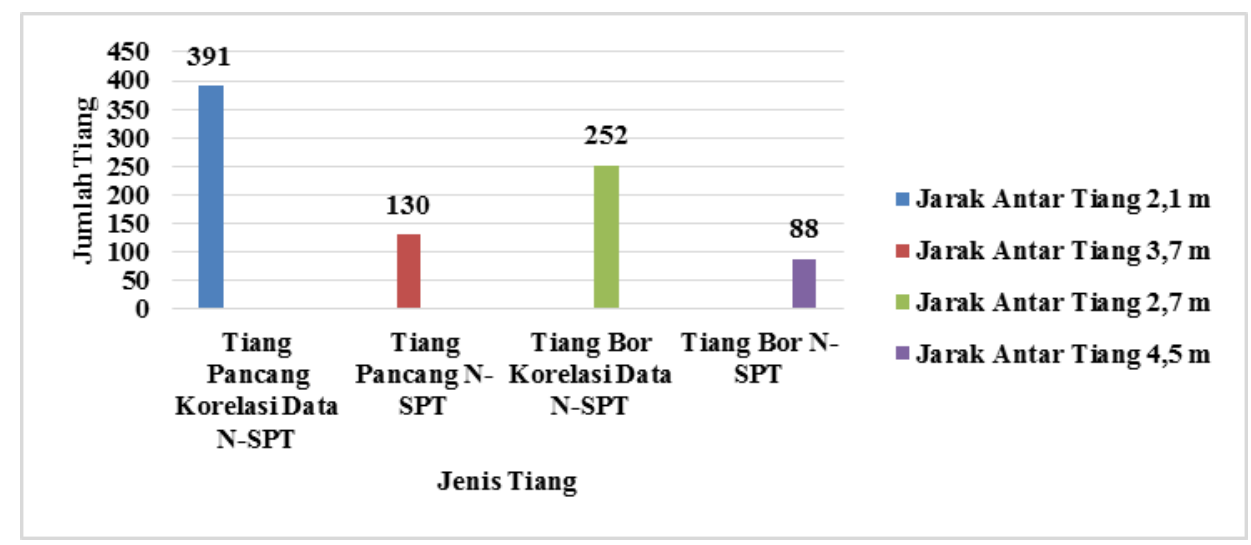

Gambar 10. Jumlah tiang

Setelah jumlah tiang didapat maka dapat dilakukan perhitungan penurunan dengan metode konvensional serta simulasi PLAXIS. Hasil salah satu penurunan pada program PLAXIS dapat dilihat pada Gambar 11 dan Gambar 12. 


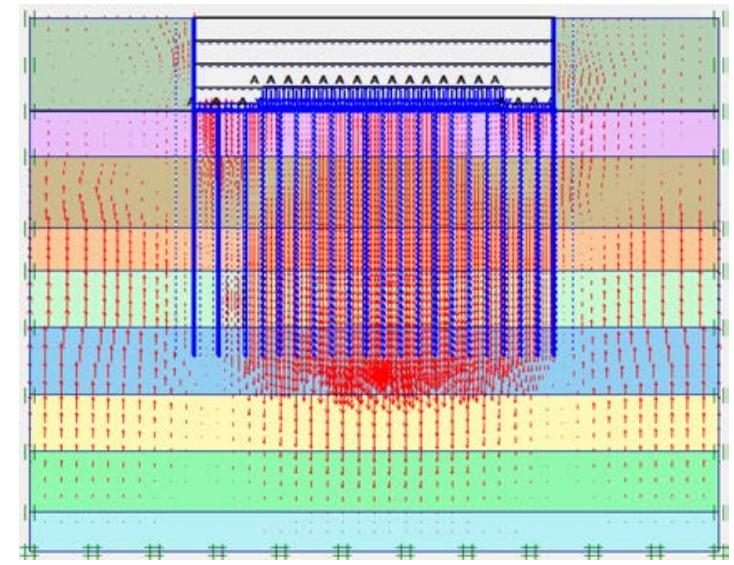

Gambar 11. Arah deformasi tiang pancang korelasi data N-SPT

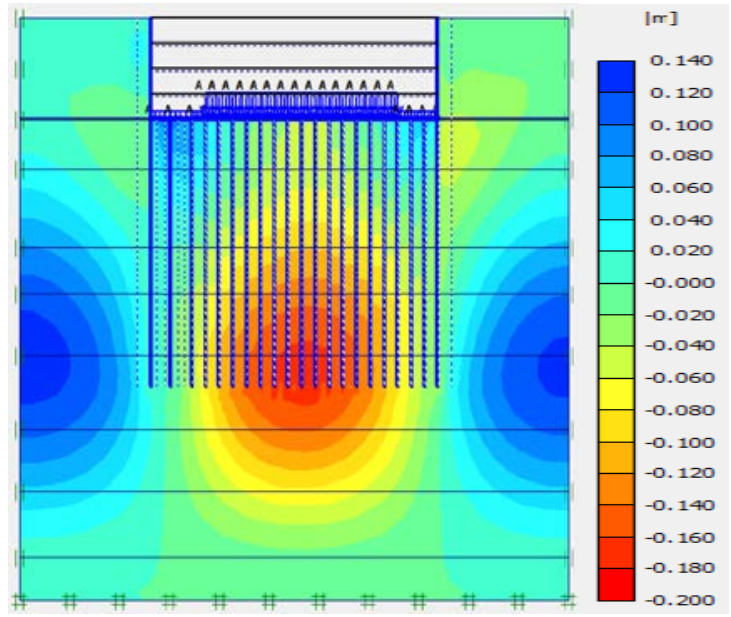

Gambar 12. Zona deformasi tiang pancang korelasi data N-SPT

Untuk hasil deformasi tiang pancang dan tiang bor berdasarkan korelasi data N-SPT dan data N-SPT dapat dilihat pada Gambar 13.

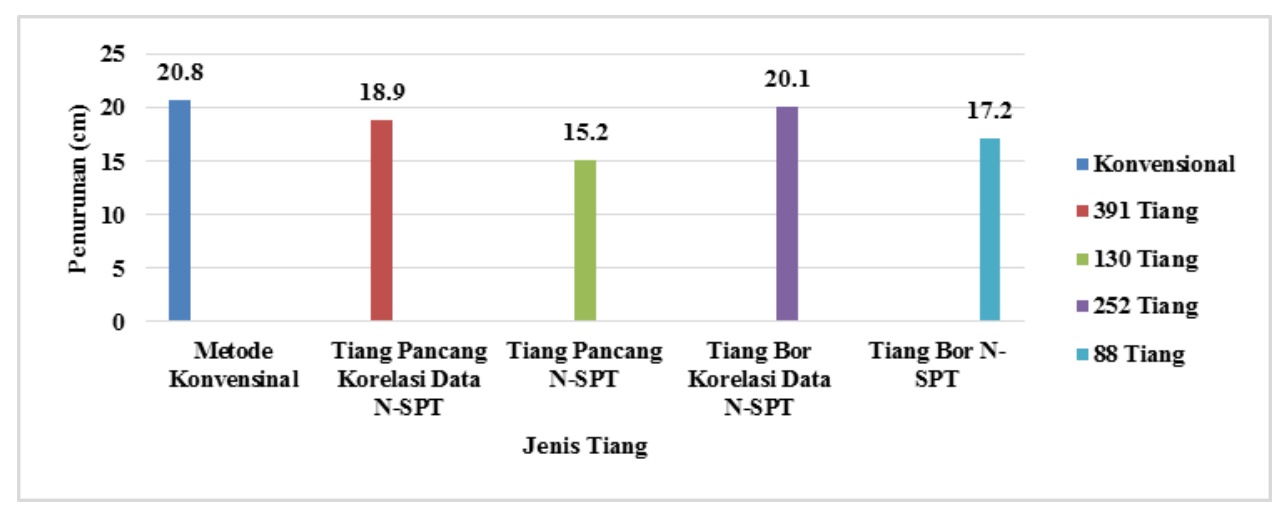

Gambar 13. Deformasi fondasi tiang dengan panjang 34,5 m

Dikarenakan hasil deformasi yang terjadi pada tiang fondasi dengan panjang 34,5 m di atas batas izin yang ditentukan yaitu sebesar 15 cm (SNI 8460 : 2017) maka dilakukan dengan memperdalam fondasi tiang dengan panjang $47 \mathrm{~m}$ atau sampai pada kedalaman $60 \mathrm{~m}$ dibawah permukaan tanah. Hasil deformasi yang terjadi dapat dilihat pada Gambar 14. 


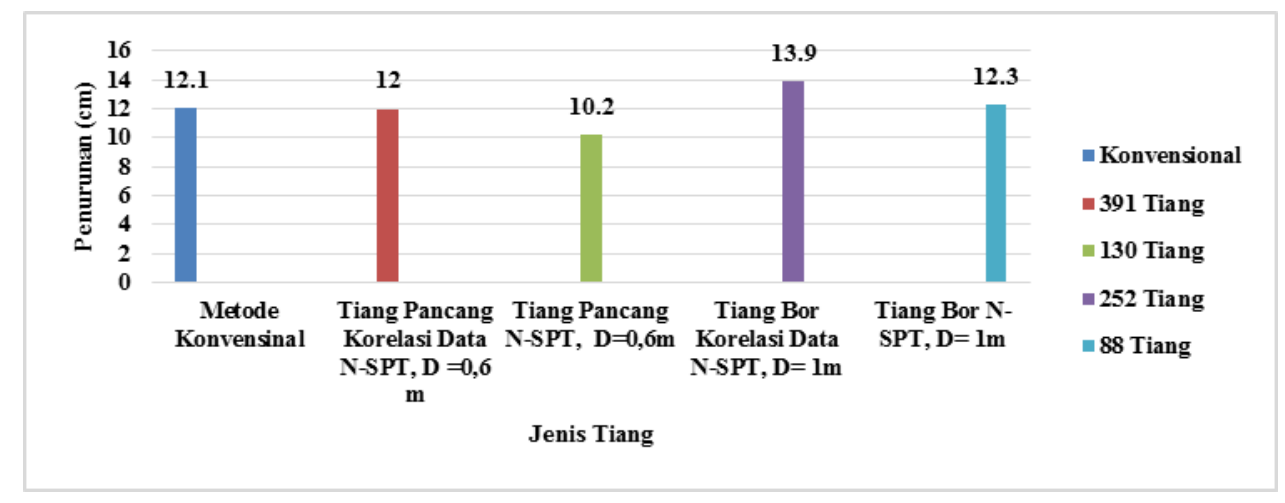

Gambar 14. Deformasi fondasi tiang dengan panjang $47 \mathrm{~m}$

\section{PENUTUP}

\section{Kesimpulan}

Berikut ini beberapa kesimpulan yang dapat di diambil dari hasil analisis fondasi dalam pada proyek pembangunan Gedung Kampus II UNTAR :

1. Berdasarkan hasil perhitungan konvensional, nilai daya dukung tiang tunggal berdasarkan korelasi data N-SPT yang digunakan lebih kecil dibandingkan dengan data N-SPT.

2. Jumlah tiang maksimum yang dibutuhkan pada daerah tower sebesar 391 tiang untuk tiang pancang berdasarkan korelasi data N-SPT sedangkan jumlah tiang minimum yang dibutuhkan sebesar 88 tiang bor berdasarkan data N-SPT.

3. Berdasarkan perhitungan konvensional dan hasil simulasi PLAXIS, penurunan pada fondasi dengan panjang tiang 34,5 m dalam kisaran 15-21 cm. Hasil tersebut tidak memenuhi syarat untuk penurunan bangunan dengan menggunakan sistem fondasi tiang dan rakit menurut SNI 8460 : $2017(<15 \mathrm{~cm})$ sehingga dilakukan dengan memperdalam panjang tiang sebesar $47 \mathrm{~m}$, penurunan yang terjadi dalam kisaran 10-14 cm.

\section{Saran}

Berdasarkan analisis yang telah dilakukan, berikut beberapa saran yang perlu diperhatikan untuk analisis lebih lanjut:

1. Untuk mendapatkan hasil yang lebih akurat disarankan menggunakan program PLAXIS 3D untuk mengetahui deformasi yang terjadi sekitar fondasi raft pile.

2. Untuk mengetahui hasil tegangan dan deformasi yang lebih akurat perlu diperhatikan simulasi urutan pemasangan dinding penahan tanah atau soldier pile dan pemasangan fondasi gedung.

\section{DAFTAR ACUAN}

Bowles, J. E. (1991). Analisa dan Desain Pondasi. Erlangga. Jakarta: Edisi Keempat Jilid 1.

Das, Braja M. (1995). Mekanika Tanah (Prinsip-Prinsip Rekayasa Geoteknis) Jilid 1. Jakarta : Erlangga.

Fransisca. (2018). Analisis Stabilitas Soldier Pile Walls pada Kondisi Beban Statis dan Dinamis dalam Proyek Pembangunan Gedung Kampus II UNTAR. Tugas Akhir, Universitas Tarumanagara.

Gibson, R.E. (1953). "Experimental determination of true cohesion and true angle of internal friction in clays". ASCE. Vol. 85. (1953) : 67-79.

Hatmoko, Adi Utomo. (2017). Laporan Perizinan Rumah Sakit Untar. Yogyakarta: P.T. Global Rancang Selaras.

Lambe, T.W. and R.V. Whitman. (1969). Soil Mechanics. New York : John Wiley and Sons.

Peck et al. (1974). Foundation Engineering. Texas : Wiley.

Rahardjo, Paulus Pramono. (2017). Manual Pondasi Tiang Edisi 5. Bandung : UNPAR.

Sakti, Solefound. (2016). Laporan Penyelidikan Tanah Pembangunan Rumah Sakit Pendidikan. Jakarta : P.T. Solefound Sakti.

Sosrodarsono, Suyono, dan Kazuto Nakazawa. (1984). Mekanika Tanah dan Teknik Pondasi. P.T. Pradnya Paramita. Jakarta: Cetakan Ketiga. 
Terzaghi, Karl and Peck, B Ralph. (1967). Soil Mechanics in Engineering Practice.John Wiley and Sons.. New York : Second Edition.

Tomlinson, M.J. (2015). Pile Design and Construction Practice. Florida : CRC Press.

Wesley, L.D. (1997). Mekanika Tanah. Jakarta : Badan Penerbit Pekerjaan Umum.

\section{DAFTAR BACAAN}

Arifin, Zainul. (2007). Komparasi Daya Dukung Aksial Tiang Tunggal Dihitung Dengan Beberapa Metode Analisis. Tesis, Universitas Diponegoro.

Das, Braja M. (2011). Principles of Foundation Engineering. Stamford: Cengage Learning.

Hadihardaja, Joetata. (1997). Pondasi Dangkal dan Pondasi Dalam. Jakarta : Gunadarma.

Hardiyatmo, H. C. (2002). Teknik Pondasi 2. Beta Offset. Yogyakarta: Edisi Kedua.

Luthfiani, Fachridia, Ilham Nurhuda dan Indrastono Dwi Atmanto. (2017). "Analisis penurunan bangunan pondasi tiang pancang dan rakit pada proyek pembangunan apartemen Surabaya central business district”. Jurnal Karya Teknik Sipil. Vol. 6. No. 2 (2017): 166-179.

Sentosa, Gregorius Sandjaja. (2015). Diktat Rekayasa Pondasi I. Jakarta: UNTAR.

Sentosa, Gregorius Sandjaja. (2015). Diktat Rekayasa Pondasi II. Jakarta: UNTAR.

Sentosa, Gregorius Sandjaja, dan Aniek Prihatiningsih. (2015). Petunjuk Pratikum Mekanika Tanah. Jakarta: UNTAR. 